\title{
Protuberance-mediated high frequency of adventitious shoot regeneration from sweetpotato leaf explants [Ipomoea batatas (L.) Lam.]
}

\author{
Halebeedu Gurusiddappa AshoK Kumar ${ }^{1,2 *}$, Amy Tsu Ku ${ }^{2}$, Pushpa Agrawal ${ }^{1}$, \\ SIDDALINGAIAH MAHESH ${ }^{1}$, KAI-WUN YEH $^{2}$ \\ ${ }^{1}$ Department of Biotechnology, R.V. College of Engineering, Mysore Road, Bangalore, India \\ ${ }^{2}$ Institute of Plant Biology, National Taiwan University, Taipei, Taiwan \\ *Corresponding author: hgashok@rvce.edu.in
}

\begin{abstract}
In this report, a novel, reproducible and efficient protocol for protuberance-mediated adventitious shoot regeneration has been established for sweetpotato [Ipomoea batatas (L.) Lam.]. The leaf explants were cultured on a modified Murashige and Skoog (MS) medium containing various concentrations $(0.5,1.0,2.0,5.0$ or $10 \mu \mathrm{M})$ of Thidiazuron (TDZ). The adventitious shoots were developed from the base of leaf explants on an MS medium supplemented with 2.0, 5.0 or $10.0 \mu \mathrm{M} \mathrm{TDZ}$. The responsive explants were transferred to a freshly modified MS medium containing TDZ. Green-colored, oval, or cone-shaped shoot-forming protuberances were developed from explants. It appeared that the frequency of protuberance development depended on the concentration of TDZ. However, this did not further improve, when the concentration of TDZ increased from 5.0 $\mu \mathrm{M}$ to $10.0 \mu \mathrm{M}$. Adventitious shoot buds were developed from protuberances, and the histology of protuberances revealed a direct origin of shoot buds. In vitro raised shoots were rooted either on a modified MS medium alone or on a modified MS medium containing indole-3-butyric acid (IBA). The regenerated plants were acclimatized and successfully established in a greenhouse.
\end{abstract}

Key words: adventitious shoots, organogenesis, plant regeneration, protuberances

\section{Introduction}

Sweetpotato [Ipomoea batatas (L.) Lam.] is the sixth most important crop in developing countries, after wheat, rice, corn, potato and barley. Sweetpotato also has potential as a biomass species for methane or ethanol production (Liu and Cantliffe, 1984). In recent years, tuber crops, particularly potato (Artsaenko et al., 1998) and sweetpotato (Berberich et al., 2005), have gained importance in molecular farming. Sweetpotato can grow under a wide range of agro-climatic conditions (Woolfe, 1992). An improvement in the quality of sweetpotato is vital since abiotic stresses, fungal and viral infections, as well as insect pests, adversely affect its productivity. Genetic improvement of sweetpotato via conventional breeding is limited due to male sterility, incompatibility and the hexaploid nature of the plant (Dhir et al., 1998). A more recent technique - genetic engineering - is the only alternative method to improve the productivity of sweetpotato. However, the lack of an efficient regeneration system is the major limiting factor which prevents the development of gene transfer technologies for commercially important cultivars of sweetpotato. There have been a number of proposals for the in vitro propagation of sweetpotato, including via adventitious shoot induction (Gosukonda et al., 1995; Dessai et al., 1995; Sihachakr et al., 1997; Santa-Maria et al., 2009) and somatic embryogenesis (Liu and Cantliffe, 1984; Chée et al., 1990; Desamero et al., 1994; Bieniek et al., 1995; Zheng et al., 1996; Dhir et al., 1998; He et al., 2009). Genetic transformation of sweetpotato, using various explants, has been reported, but with low efficiency (Newell et al., 1995; Gama et al., 1996; Morán et al., 1998; Okada et al., 2001; Berberich et al., 2005). Callus mediated transgenic plant regeneration using embryogenic suspension cultures has been reported by Yu et al., (2007), but this procedure may lead to genetic variations. It has 
been reported that plants regenerated from adventitious buds without an intervening callus phase are genetically stable (Annapurna and Rathore 2010; Liu et al., 2010). Therefore, a reproducible plant regeneration system either from individual cells or tissue without the involvement of a callus stage is essential to maintain the genetic stability of sweetpotato.

Protuberances, structures containing nodes and chlorophyll, have been developed from the node or leaf explants of Eucalyptus gunnii (Hervé et al., 2001), cotyledon explants of Parkia biglobosa (Oluwaseun and Erhinmeyoma, 2005), and hypocotyls of Passiflora alata (Pinto et al., 2010). Moreover, somatic embryos have been developed from protuberances of Parkia biglobosa (Oluwaseun and Erhinmeyoma, 2005) or shoot buds of Eucalyptus gunnii (Hervé et al., 2001).

In this paper, we report for the first time a protuberance-mediated, high frequency adventitious shoot regeneration system for sweetpotato.

\section{Materials and methods}

\section{Plant material, culture media and culture conditions}

Sweetpotato [Ipomoea batatas (L.) Lam.] cultivars Tainong 57, 64 and 66 are commercially important cultivars grown in Taiwan. Axenic cultures of Tainong 57, 64 and 66 were obtained from the Taiwan Agricultural Research Institute, Taichung, Taiwan. These cultures were maintained on a modified Murashige and Skoog's (MS, 1962) basal medium (MMS medium) containing MS salts, $0.6 \mathrm{mM}$ myo-inositol, $5 \mu \mathrm{M}$ thiamine- $\mathrm{HCl}, 10 \mu \mathrm{M}$ nicotinic acid, $5 \mu \mathrm{M}$ pyridoxine- $\mathrm{HCl}$ and $0.09 \mathrm{M}$ sucrose (Zheng et al., 1996).

The leaf explants (with lateral bud) were excised aseptically from 4/5-week-old in vitro cultures, as described by Dessai et al. (1995), and cultured onto a shoot/protuberance induction medium. In experiment 1 , leaf explants were cultured onto an MMS medium alone and also MMS supplemented with TDZ at various levels $(0.5,1.0$, $2.0,5.0,10.0$ or $20.0 \mu \mathrm{M})$. In experiment 2 , three-weekold responding leaf explants (swollen leaf base with adventitious shoots) were transferred to MMS supplemented with 5.0 or $10.0 \mu \mathrm{M}$ TDZ. For elongation of shoots, the in vitro raised shoots were transferred onto a plain basal MS medium.

The media were adjusted to $\mathrm{pH} 5.8$ before solidifying with $0.8 \%$ agar (Duchefa Biochemie, The Netherlands).
They were sterilized by autoclaving at $121^{\circ} \mathrm{C}$ for $20 \mathrm{~min}$. and dispensed aseptically into sterile bottles $(10 \times 8 \mathrm{~cm})$ or disposable Petri dishes $(2 \times 9 \mathrm{~cm})$. TDZ, vitamins and amino acids were filter sterilized through $0.45 \mu \mathrm{m}$ membrane filters (Millipore) and added to the autoclaved media. After the explants were plated onto the medium, the bottles/Petri dishes were sealed with parafilm. The cultures were incubated at $24 \pm 2{ }^{\circ} \mathrm{C}$ under a $16 \mathrm{~h}$ photoperiod (40-60 $\mu \mathrm{mol} \mathrm{m}^{-2} \mathrm{~s}^{-1}$, produced from cool-white fluorescent lights).

Elongated, well-developed individual shoots $4-6 \mathrm{~cm}$ in length and each with 3-4 leaves were separated from the cultures and transferred onto an MMS basal medium and also MMS supplemented with 2.0 $\mu \mathrm{M}$ IBA for rooting. The cultures were incubated at $24 \pm 2{ }^{\circ} \mathrm{C}$ under a $16 \mathrm{~h}$ photoperiod $\left(60 \mu \mathrm{mol} \mathrm{m} \mathrm{s}^{-1}\right)$. After two-weeks in the rooting media, the rooted plantlets were separated from culture vessels and washed thoroughly with water to remove traces of media to avoid infection by fungal contaminants. For acclimatization, the plantlets were planted into plastic pots containing peat and compost (1:1), and were incubated under controlled environmental conditions $\left(18 \pm 2^{\circ} \mathrm{C}\right.$ for a $16 \mathrm{~h}$ photoperiod, at a light intensity of $80-90 \mu \mathrm{mol} \mathrm{m}^{-2} \mathrm{~s}^{-1}$ and 70 to $80 \%$ humidity). Four-week-old hardened plants were transferred to pots containing soil and commercial compost (1:1) and maintained in a greenhouse.

\section{Histology of protuberances}

The protuberance samples from cultures were periodically collected at different intervals and fixed in FAA (Formalin, glacial acetic acid, 70\% ethanol, 10:5:85) for $12 \mathrm{~h}$ at room temperature, dehydrated through an ethanol-butyl alcohol series and embedded in paraffin wax (Fowke and Rennie, 1996). The tissues were sectioned at a thickness of $6 \mu \mathrm{m}$, stained with toluidine-blue and examined under a compound microscope (Nikon, Japan).

\section{Data collection and analysis}

The cultures were observed periodically and morphological changes were recorded at weekly intervals. All experiments were conducted in triplicate. The experiments were arranged in a randomized complete block design with six replicates in each experiment and each replicate consisting of five leaf explants. Responding explants and shoots/protuberances were counted and the results were expressed as the percentage of responding leaf 
Table 1. Effect of TDZ on adventitious shoot/protuberance induction from leaf explants of sweetpotato cvs. Tainong 57,64 and $66^{\mathrm{a}}$

\begin{tabular}{|c|c|c|c|c|c|c|c|}
\hline \multirow{3}{*}{ Cultivar } & \multicolumn{3}{|c|}{ Experiment $1^{\mathrm{b}}$} & \multicolumn{4}{|c|}{ Experiment $2^{c}$} \\
\hline & \multirow{2}{*}{$\begin{array}{l}\mathrm{TDZ} \\
(\mu \mathrm{M})\end{array}$} & \multirow{2}{*}{$\begin{array}{l}\text { responding } \\
\text { explants (\%) }\end{array}$} & \multirow{2}{*}{$\begin{array}{l}\text { number } \\
\text { of shoots }^{b}\end{array}$} & \multicolumn{2}{|c|}{$\mathrm{TDZ}(5.0 \mu \mathrm{M})$} & \multicolumn{2}{|c|}{$\mathrm{TDZ}(10.0 \mu \mathrm{M})$} \\
\hline & & & & $\begin{array}{c}\text { number } \\
\text { of protuberances }\end{array}$ & $\begin{array}{l}\text { number } \\
\text { of shoots }\end{array}$ & $\begin{array}{c}\text { number } \\
\text { of protuberances }\end{array}$ & $\begin{array}{l}\text { number } \\
\text { of shoots }\end{array}$ \\
\hline \multirow[t]{3}{*}{ TN 57} & 2.0 & 30.0 & $0.38 \mathrm{e}$ & $2.00 \mathrm{e}$ & $1.82 \mathrm{~d}$ & $1.93 \mathrm{f}$ & $1.71 \mathrm{f}$ \\
\hline & 5.0 & 57.7 & $1.68 \mathrm{~b}$ & $5.97 \mathrm{~b}$ & $5.65 \mathrm{~b}$ & $5.75 \mathrm{~b}$ & $5.45 \mathrm{~b}$ \\
\hline & 10.0 & 27.7 & $0.67 \mathrm{~d}$ & $2.63 \mathrm{~cd}$ & $2.48 \mathrm{c}$ & $2.54 \mathrm{~cd}$ & $2.14 \mathrm{de}$ \\
\hline \multirow[t]{3}{*}{ TN 64} & 2.0 & 28.8 & $0.68 \mathrm{~d}$ & $2.23 \mathrm{e}$ & $2.02 \mathrm{~d}$ & $2.14 \mathrm{ef}$ & 1.89 ef \\
\hline & 5.0 & 60.0 & $2.43 \mathrm{a}$ & $6.26 \mathrm{ab}$ & $5.83 \mathrm{~b}$ & $6.23 \mathrm{a}$ & $5.86 \mathrm{a}$ \\
\hline & 10.0 & 30.0 & $1.38 \mathrm{c}$ & $2.79 \mathrm{c}$ & $2.63 \mathrm{c}$ & $2.74 \mathrm{~cd}$ & $2.35 \mathrm{~d}$ \\
\hline \multirow[t]{3}{*}{ TN 66} & 2.0 & 27.7 & $0.68 \mathrm{~d}$ & $2.29 \mathrm{de}$ & $2.04 \mathrm{~d}$ & $2.40 \mathrm{de}$ & $1.97 \mathrm{e}$ \\
\hline & 5.0 & 62.2 & $2.42 \mathrm{a}$ & $6.53 \mathrm{a}$ & $6.19 \mathrm{a}$ & $6.27 \mathrm{a}$ & $5.90 \mathrm{a}$ \\
\hline & 10.0 & 32.2 & $1.27 \mathrm{c}$ & $2.93 \mathrm{c}$ & $2.75 \mathrm{c}$ & $2.82 \mathrm{c}$ & $2.62 \mathrm{c}$ \\
\hline
\end{tabular}

${ }^{\text {a }}$ Modified MS medium (MMS) consisting of MS salts, $0.6 \mathrm{mM}$ myo-inositol, $5 \mu \mathrm{M}$ thiamine- $\mathrm{HCl}, 10 \mu \mathrm{M}$ nicotinic acid, $5 \mu \mathrm{M}$ pyridoxine- $\mathrm{HCl}$ and $0.09 \mathrm{M}$ sucrose (Zheng et al. 1996); ${ }^{\mathrm{b}} 30$ leaf explants were cultured per treatment; ${ }^{\mathrm{c}}$ In each column, mean values followed by same letters are not significantly different according to DMRT at $P=0.05$.

Note: Explants did not show any response on primary medium devoid of TDZ or medium containing 0.5 or $1.0 \mu \mathrm{M}$ TDZ; Explants induced only callus on primary medium containing $20 \mu \mathrm{M}$ TDZ.

explants per treatment and the number of shoots/protuberances per explant per treatment. The number of shoots/protuberances from all the treatments and experiments were compared through the analysis of variance (ANOVA), and mean values were separated based on Duncan's multiple range test (DMRT).

\section{Results and discussion}

\section{Induction of adventitious shoots from leaf explants}

After one week of inoculation of leaf explants, the base of the leaf explants had become swollen and enlarged on medium containing 2.0, 5.010 .0 or $20.0 \mu \mathrm{M}$ TDZ. The adventitious buds were observed mostly on the cut edges, or in association with vascular tissue after four weeks of inoculation. The percentage of responding explants and the number of shoots were significantly influenced by the genotype and TDZ concentrations (Table 1). Leaf explants did not show any response on an MMS medium alone, or an MMS containing 0.5 or $1.0 \mu \mathrm{M}$ TDZ, while a callus was induced from explants on a medium containing $20.0 \mu \mathrm{M} \mathrm{TDZ}$ (data not shown). The largest number of shoots was induced from leaf explants either on a medium containing TDZ alone or in combination with other growth regulators in Saintpaulia ionantha (Mithila et al., 2003), Arachis correntina
(Mroginski et al., 2004), Hydrangea quercifolia (Ledbetter and Preece, 2004), Vaccinium vitis-idaea (Debnath, 2005), Pautownia tomentosa (Corredoira et al., 2008), Vaccinum corymbosum (Liu et al., 2010), Phyllanthus amarus (Nitnaware et al., 2011), Viburnum dentatum (Dai et al., 2011) and Ziziphus jujube (Ma et al., 2012). Plant regeneration in vitro was dependent on the concentration of plant growth regulators in the culture medium. In this study, 0.38 to 0.68 adventitious shoots were developed directly from the explants on a medium containing 2.0 $\mu \mathrm{M} \mathrm{TDZ}$ (Table 1). The mean number of adventitious shoots per explant was increased when the concentration of TDZ increased from $2.0 \mu \mathrm{M}$ to $5.0 \mu \mathrm{M}$ (Table 1). Similarly, in Rauvolfia tetraphylla, a greater number of shoots were induced on a medium containing $5.0 \mu \mathrm{M}$ TDZ (Faisal et al., 2005). The percentage (27.7 to $32.2 \%)$ of responding explants and the number $(0.67$ to 1.27) of shoots per explant decreased when the concentration of TDZ increased further to $10.0 \mu \mathrm{M}$ (Table 1); this is in agreement with the result for lingonberry reported by Debnath (2005). In the present study, long term exposure of explants to high concentrations $(10 \mu \mathrm{M})$ of TDZ showed a deleterious effect. Similar observations have been reported in Vaccinium angustifolium (Debnath, 2009). 

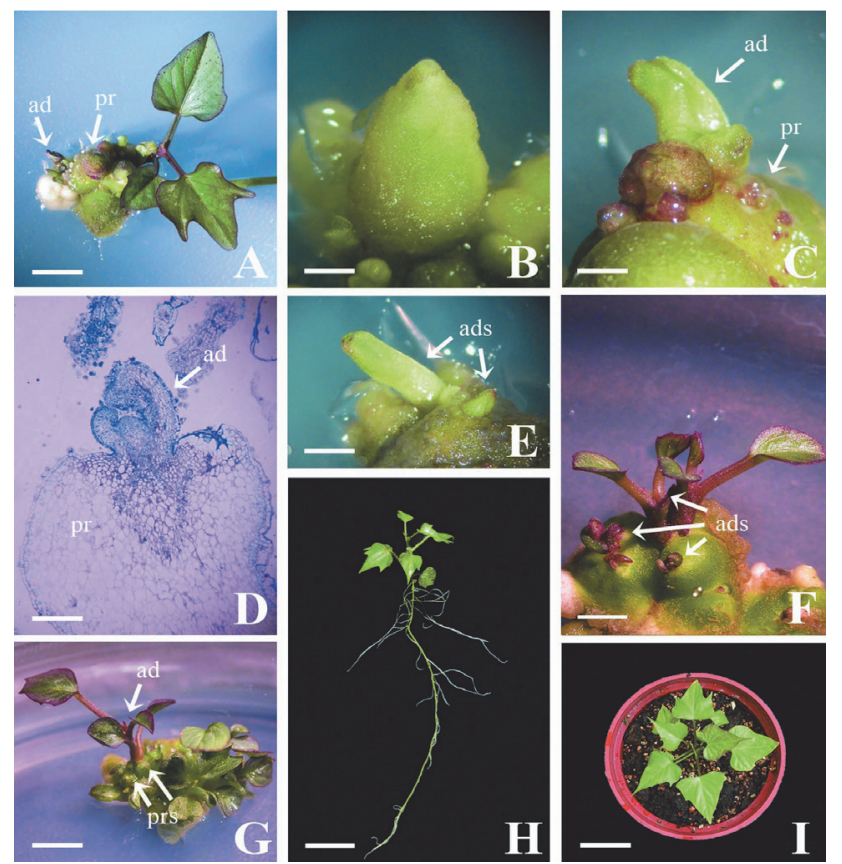

\section{Production of protuberances from leaf explants}

Protuberances were produced from explants when the responding explants were transferred to a fresh medium containing TDZ (Fig. 1A). Oval or cone-shaped protuberances were developed directly from the base of the explants and they were green in color (Fig. 1B). A similar observation has been reported for Eucalyptus gunnii (Hervé et al., 2001), where the protuberances were directly developed from leaf explants. On the other hand, callus-mediated protuberance development has been reported in Triticum aestivum (He et al., 1990). The present study revealed that the induction frequencies of protuberances were significantly affected by the genotype and the medium (Table 1). Of the two concentrations (5.0 or $10.0 \mu \mathrm{M})$ of TDZ tested, the highest number of protuberances (Table 1) was induced on a medium supplemented with $5.0 \mu \mathrm{M}$ TDZ. On a medium containing $5.0 \mu \mathrm{M} \mathrm{TDZ}, 5.97,6.26$ and 6.53 numbers of protuberances were produced from explants of cultivars TN57, TN64 and TN66, respectively. The number of protuberances did not increase when the concentration of TDZ increased from $5.0 \mu \mathrm{M}$ to $10.0 \mu \mathrm{M}$ in stage II medium (Table 1). Mithila et al. (2003) reported that shoots were induced on a medium supplemented with lower concentrations of TDZ, while higher concentrations were responsible for the production of somatic embryos from leaf and petiole explants of African violet.
Fig. 1. Protuberance-mediated plant regeneration from leaf explants of sweetpotato. A) Two-week-old subcultured explant showing direct induction of adventitious shoots and protuberances on a medium containing $5.0 \mu \mathrm{M} \mathrm{TDZ}$ (bar $=0.8 \mathrm{~cm}$ ). B) A cone-shaped protuberance $(\mathrm{bar}=0.13 \mathrm{~cm})$. C) Direct induction of adventitious shoots from protuberances on a medium containing $5.0 \mu \mathrm{M}$ TDZ (bar $=0.15 \mathrm{~cm}$ ). D) A longitudinal section showing direct induction of shoots from a protuberance ( $\mathrm{bar}=0.8 \mathrm{~mm}$ ). E) Direct development of adventitious shoots from a protuberance on a medium containing 5.0 $\mu \mathrm{M} \mathrm{TDZ}$ (bar $=0.15 \mathrm{~cm}$ ). F) Protuberanceinduced adventitious shoots at different developmental stages (bar $=0.2 \mathrm{~cm}) . \mathrm{G})$ Elongation of protuberance-induced adventitious shoots $(\mathrm{bar}=0.8 \mathrm{~cm})$. H) Well-grown rooted plantlet $(\mathrm{bar}=$ $3 \mathrm{~cm})$. I) An acclimatized in vitro grown plant (bar $=3 \mathrm{~cm}) .(\mathrm{ad}$ - adventitious shoot; pr - protuberance; ads - adventitious shoots; prs - protuberances).

In this study, the protuberances and shoots were produced from explants on a medium containing TDZ.

\section{Induction of shoots from protuberances}

Hervé et al. (2001) reported that shoot buds were directly induced from the protuberances of Eucalyptus gunnii. Similarly, in this study, adventitious shoots were directly developed from protuberances in another two weeks (Fig. $1 \mathrm{C}$ and $1 \mathrm{E}$ ), their development being TDZ-dependent (Table 1). A longitudinal section of protuberance revealed that the shoots were directly developed from the protuberance (Fig. 1D). A higher number of shoots developed from protuberances on a medium containing $5.0 \mu \mathrm{M} \mathrm{TDZ}$ compared to a medium containing 10.0 $\mu \mathrm{M}$ TDZ (Table 1). Gosukonda et al. (1995) and Santa-Maria et al. (2009) also reported adventitious shoot induction from leaf explants of sweetpotato on a stage II medium, where the explants were incubated for a few days on a medium containing auxins, and were subsequently transferred to a medium supplemented with cytokinins, which resulted in the development of 1-2 shoots per explant with a significant genotype and media interaction. In this study, we obtained relatively few-times more shoots per explant compared to earlier reports (Gosukonda et al., 1995; Santa-Maria et al., 2009). A few shoots were induced from leaf explants on TDZ (0.5-20.0 $\mu \mathrm{M})$ containing medium. However, the 
number of shoots was improved when the explants were transferred to a medium containing 5.0 $\mu \mathrm{M}$ TDZ. Similar observations have also been reported for Jatropha curcas (Sujatha et al., 2005). The adventitious shoots exhibited further growth on a medium containing $5.0 \mu \mathrm{M} \mathrm{TDZ}$ (Fig. $1 \mathrm{~F}$ and $1 \mathrm{G}$ ). However, stunted shoot growth was observed on a medium containing $10.0 \mu \mathrm{M} \mathrm{TDZ}$, and this became normal when transferred to an MS basal medium.

\section{Rooting and acclimatization}

In vitro grown shoots with 3-4 leaves were excised and cultured onto an MS medium alone or an MS supplemented with $2 \mu \mathrm{M}$ IBA for rooting. The roots were observed after a few days (4 to 6 days) of culture, and there was no significant difference between the two media used for rooting (data not shown). The percentage of rooting was $100 \%$ and 3 to 5 roots were observed in each culture. The maximum number (4 to 5 ) of roots was induced on a medium supplemented with IBA when compared to the MS basal medium (3 to 4 roots). Wellrooted (3 to 4 inches in length) plantlets (Fig. $1 \mathrm{H}$ ) were removed from cultures and washed thoroughly with sterilized water to remove traces of media, and transplanted into plastic pots containing autoclaved peat and compost (1:1). The acclimatized in vitro grown plants (Fig. 1I) did not exhibit any abnormalities/changes compared to parent plants. After acclimatization, the regenerated plants were transferred to a greenhouse for further growth.

In this study, we have developed a highly efficient plant regeneration system for sweetpotato. The greatest number of shoots/protuberances were produced directly from explants, without the intervening callus phase, on a medium containing $5.0 \mu \mathrm{M} \mathrm{TDZ}$. In addition, this protocol for in vitro adventitious shoot induction using protuberances may be used to provide an alternate target tissue for the transformation of sweetpotato.

\section{Acknowledgements}

The authors are grateful to the National Science Council, Taipei, Taiwan for financial support (NSC-92-2311-13-002024). We thank Dr. Hann-Chung Lo, Forest Department, National Taiwan University, Taipei, Taiwan for providing facilities for histology. We are also thankful to Mr. Yi-Ming Li and Cuan-Way Chen for technical assistance.

\section{References}

Annapurna D., Rathore T.S. (2010) Direct adventitious shoot induction and plant regeneration of Embelia ribes Burm F. Plant Cell Tissue Organ. Cult. 101: 269-277.

Artsaenko O., Kettig B., Fiedler U., Conrad U., Düring K. (1998) Potato tubers as a biofactory for recombinant antibodies. Mol. Breed. 4: 313-319.

Berberich T., Takagi T., Miyazaki A., Otani M., Shimada T., Kusano T. (2005) Production of mouse adiponectin, an antidiabetic protein, in transgenic sweetpotato plants. J. Plant Physiol. 162: 1169-1176.

Bieniek M.E., Harrell R.C., Cantliffe D.J. (1995) Enhancement of somatic embryogenesis of Ipomoea batatas in solid cultures and production of mature somatic embryos in liquid cultures for application to a bioreactor production system. Plant Cell Tiss. Org. Cult. 41: 1-8.

Chée R.P., Schultheis J.R., Cantliffe D.J. (1990) Plant recovery from sweetpotato somatic embryos. HortSci. 25: 795-797.

Corredoira E., Ballester A., Vieitez A.M. (2008) Thidiazuroninduced high-frequency plant regeneration from leaf explants of Paulownia tomentosa mature trees. Plant Cell Tiss. Org. Cult. 95: 197-208.

Dai W., Su Y., Castillo C., Beslot O. (2011) Plant regeneration from in vitro leaf tissues of Viburnum dentatum $L$. Plant Cell Tiss. Org. Cult. 104: 257-262.

Debnath S.C. (2005) A two-step procedure for adventitious shoot regeneration from in vitro-derived lingonberry leaves: shoot induction with $T D Z$ and shoot elongation using zeatin. HortSci. 40: 189-192.

Debnath S.C. (2009) A two-step procedure for adventitious shoot regeneration on excised leaves of lowbush blueberry. In Vitro Cell Dev. Biol. Plant 45: 122-128.

Desamero N.V., Rhodes B.B., Decoteau D.R., Bridges W.C. (1994) Picolinic acid-induced direct somatic embryogenesis in sweetpotato. Plant Cell Tiss. Org. Cult. 37: 103-111.

Dessai A.P., Gosukonda R.M., Blay E., Dumenyo C.K., Medina-Bolivar F., Prakash C.S. (1995) Plant regeneration of sweetpotato (Ipomoea batatas L.) from leaf explants in vitro using a two-stage protocol. Sci. Horti. 62: 217-224.

Dhir S.K., Oglesby J., Bhagsari A.S. (1998) Plant regeneration via somatic embryogenesis, and transient gene expression in sweetpotato protoplasts. Plant Cell Rep. 17: 665-669.

Faisal M., Ahmad N., Anis M. (2005) Shoot multiplication in Rauvolfia tetraphylla L. using thidiazuron. Plant Cell Tiss. Org. Cult. 80: 187-190.

Fowke L.C., Rennie P.J. (1996) Botanical microtechnique for plant cultures. In: Plant Cell, Tissue and Organ Culture, Fundamental methods, eds. Gamborg O.L., Phillips G.C., Narosa Publishing House, New Delhi, pp. 217-228.

Gama M.I.C.S., Leite Jr. R.P., Cordeiro A.R., Cantliffe D.J. (1996) Transgenic sweet potato plants obtained by Agrobacterium tumefaciens-mediated transformation. Plant Cell Tiss. Org. Cult. 46: 237-244.

Gosukonda R.M., Dessai A.P., Blay E., Prakash C.S., Peterson C.M. (1995) Thidiazuron-induced adventitious shoot re- 
generation of sweetpotato (Ipomoea batatas). In Vitro Cell Dev. Biol. Plant 31: 65-71.

He D.G., Yang Y.M., Bertram J., Scott K.J. (1990) The histological development of the regenerative tissue derived from cultured immature embryos of wheat (Triticum aestivum L.). Plant Sci. 68: 103-111.

He S., Han Y., Wang Y., Zhai H., Liu Q. (2009) In vitro selection and identification of sweetpotato (Ipomoea batatas (L.) Lam.) plants tolerant to NaCL. Plant Cell Tiss. Org. Cult. 96: 69-74.

Hervé P., Jauneau A., Pâques M., Marien J.-N., Boudet A.M., Teulières C. (2001) A procedure for shoot organogenesis in vitro from leaves and nodes of an elite Eucalyptus gunnii clone: comparative histology. Plant Sci. 161: 645-653.

Ledbetter D.I., Preece J.E. (2004) Thidiazuron stimulates adventitious shoot production from Hydrangea quercifolia Bartr. leaf explants. Sci Horti. 101: 121-126.

Liu C., Callow P., Rowland L.J., Hancock J.F., Song G.-Q. (2010) Adventitious shoot regeneration from leaf explants of southern high bush blueberry cultivars. Plant Cell Tiss. Org. Cult. 103: 137-144.

Liu J.R., Cantliffe D.J. (1984) Somatic embryogenesis and plant regeneration in tissue cultures of sweetpotato (Ipomoea batatas Poir.). Plant Cell Rep. 3: 112-115.

Ma C., Ye X., Chen Y., Feng J., Shang X., Li J., Wu Y., Hu J. (2012) Anatomical observations of adventitious bud regeneration from leaf explants of Ziziphus jujube Mill. 'Huizao'. Hort. Environ. Biotechnol. 53: 316-319.

Mithila J., Hall J.C., Victor J.M.R., Saxena P.K. (2003) Thidiazuron induces shoot organogenesis at low concentrations and somatic embryogenesis at high concentrations on leaf and petiole explants of African violet (Saintpaulia ionantha Wendl.). Plant Cell Rep. 21: 408-414.

Mok M.C., Mok D.W.S., Armstrong D.J., Shudo K., Isogai Y., Okamoto T. (1982) Cytokinin activity of $N$-phenyl-N-1,2,3thidiazol-5-ylurea (thidiazuron). Phytochemistry 21: 15091511.

Moran R., Garca R., Lopez A., Zaldua Z., Mena J., Garca M., Armas R., Somonte D., Rodrguez J., Gomez M., Pimentel E. (1998) Transgenic sweet potato plants carrying the delta-endotoxin gene from Bacillus thuringiensis var. tenebrionis. Plant Sci. 139: 175-184.

MroginskiE., Rey H.Y., GonzalezA.M., MroginskiL.A. (2004) Thidiazuron promotes in vitro plant regeneration of Arachis correntina (Leguminosae) via Organogenesis. J. Plant Growth Reg. 23: 129-134.
Murashige T., Skoog F. (1962) A revised medium for rapid growth and bioassays with tobacco tissue culture. Physiol. Plant. 15: 473-497.

Murthy B.N.S., Murch S.J., Saxena P.K. (1998) Thidiazuron: a potent regulator of in vitro plant morphogenesis. In Vitro Cell Dev. Biol. 34: 267-275.

Newell C.A., Lowe J.M., Merryweather A., Rooke L.M., Hamilton W.D.O. (1995) Transformation of sweetpotato (Ipomoea batatas (L.) Lam.) with Agrobacterium tumefaciens and regeneration of plants expressing cowpea trypsin inhibitor and snowdrop lectin. Plant Sci. 107: 215-227.

Nitnaware K.M., Naik D.G., Nikam T.D. (2011) Thidiazuroninduced shoot organogenesis and production of hepatoprotective lignan phyllanthin and hypophyllanthin in Phyllanthus amarus. Plant Cell Tiss. Org. Cult. 104: 101-110.

Okada Y., Saito A., Nishiguchi M., Kimura T., Mori M., Hanada K., Sakai J., Miyazaki C., Matsuda Y., Murata T. (2001) Virus resistance in transgenic sweetpotato [Ipomoea batatas L. (Lam)] expressing the coat protein gene of sweetpotato feathery mottle virus. Theor. Appl. Genet. 103: 743751.

Pinto A.P.C., Monteiro-Hara A.C.B.A., Stipp L.C.L., Mendes B.M.J. (2010) In vitro organogenesis of Passiflora alata. In Vitro Cell Dev. Biol. Plant. 46: 28-33.

Santa-Maria M., Pecota K.V., Yencho C.G., Allen G., Sosinski B. (2009) Rapid shoot regeneration in industrial 'high starch'sweetpotato (Ipomoea batatas L.) genotypes. Plant Cell Tiss. Org. Cult. 97: 109-117.

Sihachakr D., Haïcour R., Alves J.M.C., Umboh I., Nzoghé D., Servaes A., Ducreux G. (1997) Plant regeneration in sweetpotato (Ipomoea batatas L., Convolvulaceae). Euphytica 96: 143-152.

Sujatha M., Makkar H.P.S., Becker K. (2005) Shoot bud proliferation from axillary nodes and leaf sections of non-toxic Jatropha curcas L. Plant Growth Reg. 47: 83-90.

Woolfe J.A. (1992) Sweetpotato, an untapped food resource. Cambridge University Press, New York.

Yu B., Zhai H., Wang Y., Zang N., He S., Liu Q. (2007) Efficient Agrobacterium tumefaciens - mediated transformation using embryogenic suspension cultures in sweetpotato, Ipomoea batatas (L.) Lam. Plant Cell Tiss. Org. Cult. 90: 265-273.

Zheng Q., Dessai A.P., Prakash C.S. (1996) Rapid and repetitive plant regeneration in sweetpotato via somatic embryogenesis. Plant Cell Rep. 15: 381-385. 